\title{
System Model of Professional Development Process
}

\author{
Iryna Partyka \\ postgraduate student of Economic and Management Department \\ Drohobych Ivan Franko State Pedagogical University, Ukraine \\ ORCID iD: https://orcid.org/0000-0001-8381-252X e-mail: parira78@gmail.com
}

\begin{abstract}
System approach to management professional development organization is explored in the article. The importance and urgency of the problem of personnel development of a modern organization in a competitive environment is proved. The professional development of personnel as a component of personnel management and a means of increasing the competitiveness of the organization is considered. Different views of scientists on the definition of personnel development, professional development and personnel development system have been clarified. The tasks of professional development of personnel are outlined. System model of professional development process has been developed. The elements of the developed model are characterized, namely: development of professional staff development strategy; setting goals and objectives for professional development of staff; organization of professional development process; diagnosing the needs of professional development of staff; drawing up a plan for professional development of staff; budgeting professional development; determining areas of staff training; definition of methods and forms of teaching; implementation of the staff training process and evaluation of the effectiveness of professional staff training.

Keywords: personnel, personnel development, professional development of personnel, personnel development system, management of professional development of personnel.

Formulation of the problem. In conditions of market competition, it is important for effective business to pay attention to the problem of staff development of the organization. Distinctive characteristics are the competitiveness of staff, their professional competencies (knowledge, skills, practical skills, abilities developed through training) and competence (according to Leontian M., «competence is the result of the acquisition of competencies» and «it has an integral element of readiness to perform the task, and also includes in its concept elements of personal characteristics (mobility, initiative, etc.) [1, p. 75]). These components must be considered when creating and improving the professional development of personnel. It should be noted that this system must be clearly planned and organized, it must operate on an ongoing basis, it must respond flexibly to challenges and changes in both internal and external environment of the enterprise. The importance and appropriateness of management professional development is clear and relevant for any organization.
\end{abstract}

Selection of previously unsolved parts of the overall problem. Many studies of researchers are devoted to the problems of staff development, but there is a need for improvement using a systematic approach. The purpose of such measures is to make them as effective as possible, and the costs of these measures are converted into investments as soon as possible.

The purpose of the article. The main purpose of the study is to develop a system model of professional development process. 
Results. The main and important role in the personnel management system of the organization is played by professional development. Previously, professional development was understood as advanced training in order to improve professional qualities. This process was funded by the state and ended with a diploma or certificate. However, in modern market conditions, professional development of staff is considered as a component of personnel management. This component is a determining indicator of the effectiveness of the organization. Personnel is considered the main resource of the enterprise, which affects its competitiveness in a globalized economy. Therefore, the professional development of staff has become a strategic task at all levels of government. V. Savchenko considers staff development as a systematically organized process of continuous professional training of employees to prepare them for new production functions, professional development, the formation of a reserve of managers and improving the social structure of staff [2, p. 17]. A. Tkachenko expanded and supplemented this definition: professional development of staff is a purposeful and systematic impact on employees through professional training during their work in the organization in order to achieve high efficiency of production or services, increase staff competitiveness in the labor market, ensure employee performance new more complex tasks based on the maximum possible use of their abilities and potential [3, p. 194].

Since for our research it is important to systematize the management of professional development of staff, it is appropriate to mention T. Zbrytska, she formulated the concept of "personnel development system" as a set of organizational structures, methods, processes and resources necessary for the effective implementation of current and future tasks in the field of personnel development, as well as optimal satisfaction of employees' requests related to selfrealization, training and career [4, p. 369]. The tasks of professional development of staff are to find capable employees who are able to learn; staff capacity development; emphasis on creativity and innovation of vocational training; the presence of healthy competition among professionals; introduction of continuing education for the purpose of continuous improvement; work on the formation of a reserve of managers; staff career planning and development. After researching, analyzing and organizing the results of work of Ukrainian and foreign scientists on staff development, system model of professional development process was developed. This model contains the following elements Fig. 1:

1. 1. development of professional staff development strategy in view of its adaptation to rapidly changing environmental conditions;

2. setting goals and objectives of professional development of staff that are based on the organizational goal (Goals must be clear, specific, measurable and achievable.);

3. organization of professional development process; 
4. diagnosing the needs of professional development of staff Fig. 2 (It is necessary to establish a discrepancy between the required level and the actual level of staff development that should have staff to achieve current and future goals, objectives of the organization; the need is to assess the gap between the required and existing levels of knowledge, skills, abilities and professional experience of staff; based on this assessment, priorities for staff development are formed.);

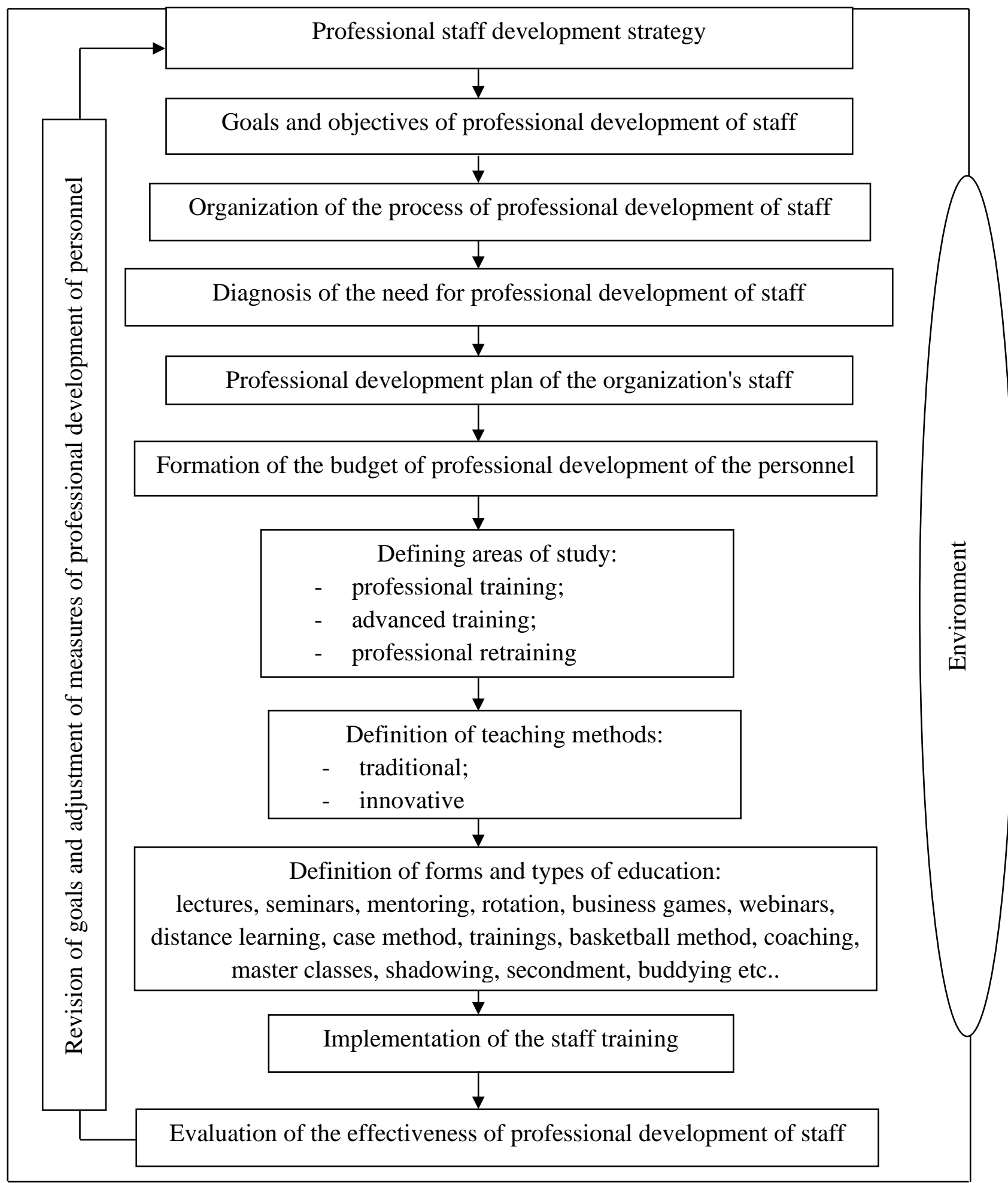

Figure 1. System model of professional development process [developed by the author] 
5. drawing up a plan for professional development of staff (The plan includes an annual period, indicating the number of employees who will study in the plan period subject areas, methods, forms and terms of learning.);

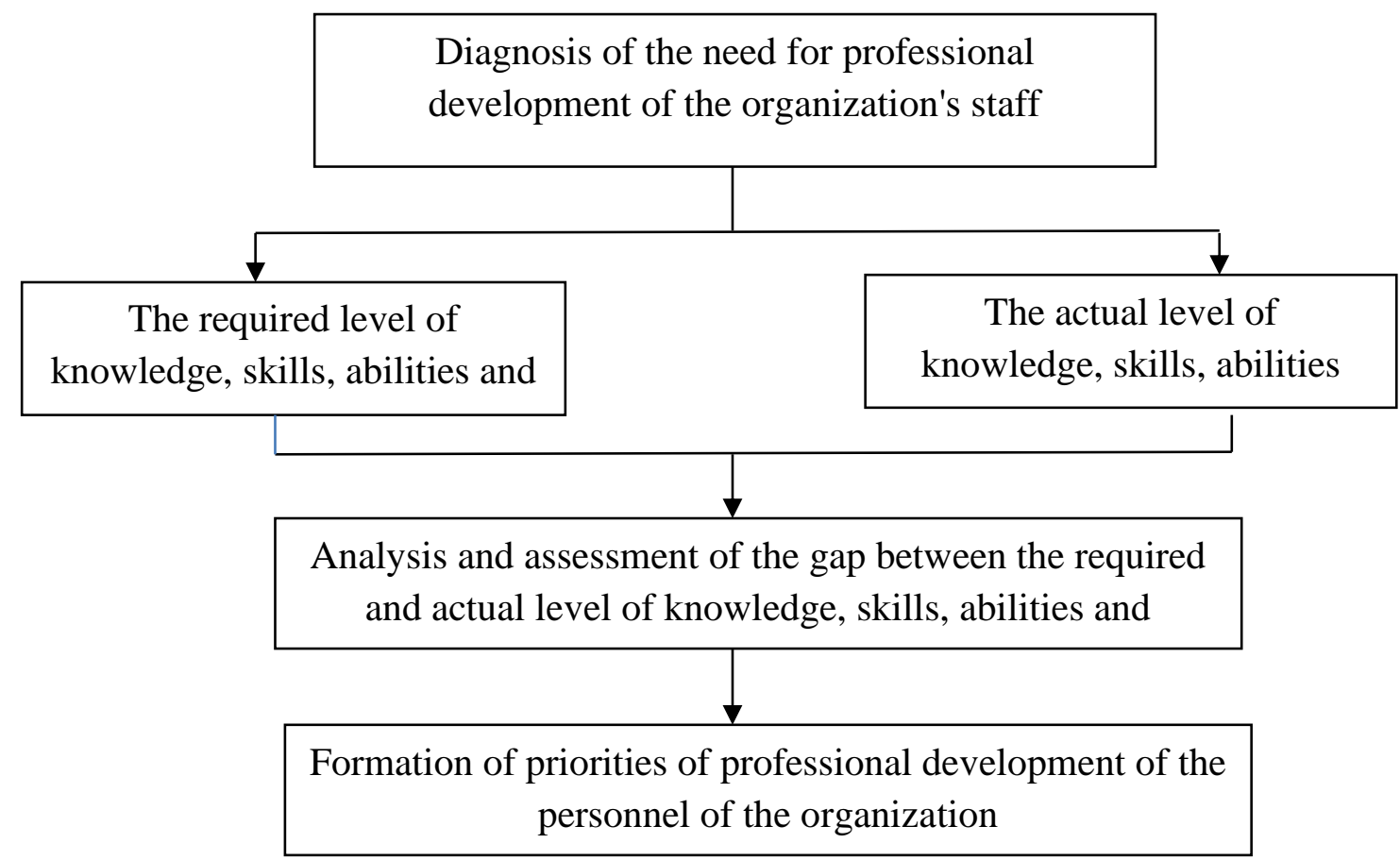

Figure 2. Diagnosis of the need for professional development of the organization's staff [developed by the author]

6. budgeting professional development (The plan includes an annual period, indicating the number of employees who will study in the plan period subject areas, methods, forms and terms of learning. The needs of the organization in the professional development of staff, financial opportunities affect the formation of the size of the budget for staff development. The state plays an important role in developed countries in promoting staff development. It introduces income tax rebates for companies that have spent money on staff development. Levchenko A. proposes to solve this issue through exemption of funds aimed at targets proficiency training, subsidies (grants) due to the reallocation of funds received as a result of targeted tax and by reimbursement [5, p.158-159].);

7. determining areas of staff training (There are professional training, advanced training and professional retraining. Vocational training consists of systematic training in order to obtain qualifications for various types of human activity. Professional development is understood as training to improve knowledge, skills and abilities. Retraining is training, its purpose is to acquire new knowledge, skills and abilities to master a new profession.); 
8. definition of methods and forms of teaching (Currently, there are many traditional and modern methods of staff training. Traditional methods include lectures, seminars, conferences, coaching, mentoring, rotation, internships, project team work, business games, self-study; Innovative methods include webinars, distance learning, modular learning, case method, trainings, brainstorming, basketball method, master classes, action learning, shadowing, secondment, buddying, coaching.);

9. implementation of the staff training process (This stage involves the learning process itself and as a result of acquiring and improving professional knowledge, skills and abilities.);

10. evaluation of the effectiveness of professional staff training (It is possible to check the knowledge, abilities and skills acquired by the personnel after the termination of training by means of various forms of control: examinations, tests, results of passing of practices, performance of research works. The next step of the test is in the organization itself in the direct performance of duties and the practical application of acquired knowledge and skills. Such control is more decisive in assessing the effectiveness of staff training.).

Feedback is important in the system of the organization process professional development that affects the view stated objectives and provides for adjustments if necessary measures for professional development organization.

Conclusions. It is important to note that the personnel development system must be flexible to changes in the market environment, the internal needs of the organization through the ability to change the content, methods and organizational forms. The developed system model of professional development process contributes to the improvement of the acquired and mastering of qualitatively new knowledge, skills and abilities of the employee, increasing his professional level. Thus, the professional development of staff provides professional, intellectual, moral, personal growth of employees, contributes to the growth of its competitiveness in the labor market.

\section{References}

1. Leontian M. A. (2012). The concepts of "competence" and "competence" in the theory of education. Naukovi pratsi Chornomorskoho derzhavnoho universytetu imeni Petra Mohyly kompleksu "Kyievo-Mohylianska akademiia". Ser. : Pedahohika, 188 (176). Retrieved from: http://nbuv.gov.ua/UJRN/Npchduped_2012_188_176_18 [in Ukrainian].

2. Savchenko V.A. (2002). Personnel development management. Kiev: KNEU [in Ukrainian].

3. Tkachenko A.M. (2014). Professional development of staff is an urgent task today. Ekonomichnyi visnyk Donbas,. 1 (35), 194-197. [in Ukrainian].

4. T.P. Zbrytska, H.O. Savchenko, M.S. Tatarevska. (2013). Personnel development management. Odessa: Atlant [in Ukrainian]. 
5. Levchenko A. O. (2005). Methodical approaches to personnel development management at the enterprise. Naukovi pratsi Kirovohradskoho natsionalnoho tekhnichnoho universytetu: Ekonomichni nauky, 2 (7). Retrieved from:

http://dspace.kntu.kr.ua/jspui/bitstream/123456789/3228/1/26.pdf [in Ukrainian].

Translation of the Author's Name and Affiliation to the Original Language

\section{Ірина Партика}

аспірант кафедри економіки та менеджменту

Дрогобиџький державний педагогічний університет ім. І.Франка, Украӥна 